\title{
THE ALTAR AND ITS DECORATIONS \\ IN MEDIEVAL CHURCHES. \\ A FUNCTIONALIST APPROACH
}

\author{
Justin E. A. Kroesen \\ University of Groningen \\ j.e.a.kroesen@rug.nl
}

\begin{abstract}
It is the aim of this article to problematize the concept of the medieval altarpiece or retable. If handbook definitions of a formal nature are followed, many configurations which actually occur in medieval churches remain overlooked. In order to understand the pluriformity of medieval altar decorations, a functional definition seems more helpful, such as 'any object or depiction on top of or behind the altar that forms a backdrop to liturgical activity on and around the altar'. Altars were sometimes equipped with objects which could adopt the function of an altarpiece, including reliquaries and saints' sculptures, while others were provided with painted or sculptured backdrops which often blend in with the architecture of the building. In addition, many medieval altar decorations display a fundamentally composite character, with clear distinctions between formal categories such as frontals, altar sculptures, panel retables, tabernacles and shrines being difficult to maintain. To gain a better insight into the true variety of medieval altar decorations, special attention should be paid to side altars. Re-evaluating these fixtures as a basic element of the medieval church interior enables us to form a more realistic picture of the variety of medieval altar furnishings and to better understand the original context of the many loose objects we now admire in churches and museums.
\end{abstract}

\section{Keywords}

Medieval liturgy, retable, altarpiece, tabernacle, sculpture, painting.

\section{Resumen}

El afán de este artículo es problematizar el concepto del retablo medieval. Si seguimos la definición formal como suele aparecer en los manuales de historia del 
arte, numerosas configuraciones que ocurren en la actualidad en iglesias medievales permanecen ignorados. Para entender la pluriformidad de las decoraciones del altar medieval, parece más útil adoptar una definición funcional, como la de 'cualquier objeto o representación encima o detrás del altar que sirve de telón de fondo a la actividad litúrgica en y alrededor del altar'. Altares podían ser equipados con objetos que asumían la función de un retablo, como por ejemplo relicarios y esculturas de santos, mientras que otros fueron proporcionados de un fondo pintado o esculpido que a menudo se mezclaba con la arquitectura del edificio. Además, muchas decoraciones del altar medievales presentan un carácter fundamentalmente compuesto, con lo cual claras distinciones entre categorías formales, como frontal de altar, escultura, retablo-panel y tabernáculo son difíciles de mantener. Para ganar una mejor idea de la variedad de las decoraciones del altar medieval, se debería prestar especial atención a los altares laterales. Una re-evaluación de este accesorio como un elemento básico del interior de la iglesia medieval nos permite formar una imagen más realista de la variedad de mobiliario del altar medieval y mejor comprender el contexto original de muchos objetos sueltos que hoy admiramos en iglesias y museos.

\section{Palabras clave}

Liturgia medieval, retablo, frontal de altar, tabernáculo, escultura, pintura.

Among all liturgical furnishings of medieval cathedrals and other church buildings, pride of place was taken by the retable or altarpiece. In their wonderful volume on the Gothic winged altarpieces of Central Europe, Rainer Kahsnitz and Achim Bunz describe them as 'the most outstanding and distinguished works of

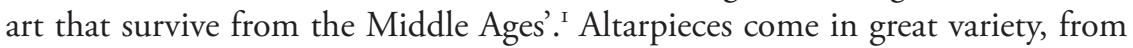
small to large, plain or colourful, with or without wings. Our image of the medieval altarpiece is strongly shaped by a number of outstanding examples, such as Duccio's 'Maestà, Matthias Grünewald's Isenheimer Altar and the imposing retablo of Toledo Cathedral. However, what exactly counts as an altarpiece and what not? What about, for example, Michelangelo's Last Judgement? Although it adorned the wall above the altar in the Sistine Chapel, very few regard this masterpiece as an altar retable.

${ }^{I}$ Rainer Kahsnitz and Achim Bunz, Die großen Schnitzaltäre. Spätgotik in Süddeutschland, Österreich, Südtirol (Munich: Hirmer, 2005). English edition: Carved Splendor. Late Gothic Altarpieces in Southern Germany, Austria, and South Tirol (Los Angeles: Getty Publications, 2006). 
Ever-expanding Wikipedia defines the 'altarpiece' as follows:

An altarpiece is a picture or relief representing a religious subject and suspended in a frame behind the altar of a church. The altarpiece is often made up of two or more separate panels created using a technique known as panel painting. It is then called a diptych, triptych or polyptych for two, three, and multiple panels respectively. ${ }^{2}$

This definition implies that altarpieces must have frames and be composed of different panels, primarily painted ones. A quick scan of art historical glossaries and handbooks reveals that the rendering of the subject matter usually follows similar lines. The evolution is traditionally presented in a linear way, from small to large and from simple to complex, whereby the emergence of the triptych and the polyptych often seems to be regarded as the natural outcome of a long, gradual process. ${ }^{3}$

To understand the true nature of the medieval altarpiece in all its variety, however, it would be much more fruitful to replace the formal definition of an altarpiece with a functional one. If the altarpiece was approached functionally, for example as 'any object or depiction on top of or behind the altar that forms a backdrop to liturgical activity on and around the altar', our scope would become significantly wider. A variety of object types now come into play, including statues, shrines, reliquaries, wall paintings, wall niches and architectural structures. It is the aim of this article to paint a new picture of the medieval retable landscape by adopting such a functional definition. The following sections provide a succinct survey of the variety of forms and solutions, discussing a number of examples from different European countries and regions, including Germany, Scandinavia, the Low Countries, England, France and Spain. The limited scope of this article allows for only a few general sketches of the variety, while also offering some notes towards a more open and encompassing working definition.

It will be shown that in many instances objects and other elements were integrated alongside each other into composite ensembles. It will also become clear

2 Wikipedia s.v. 'Altarpiece', retrieved July 2013.

3 The Oxford Companion to Christian Art and Architecture (New York: Oxford University Press, I996), describes this process as follows: 'A retable began, like a predella, by being a shelf (Lat. retabulum, rear table) at the back of an altar, used for ornaments. It progressed to being part of the framework of panels forming a reredos, and finally became another name for an altarpiece, either painted or carved, which was made up of one or more panels which were fixed together, i.e. not hinged like a triptych $[\ldots]$ '. 
that by changing the definition of the altarpiece from a formal to a functional one, it sometimes becomes difficult to establish where the altarpiece starts and ends. Thus, the architecture of a church building may assume the function of an altarpiece, while triptychs or polyptychs are sometimes surrounded or surmounted by paintings which add to the overall composition. Four specific categories will be discussed, namely I) reliquaries and tabernacles, 2) altar sculptures and 'tabernacle shrines', 3) wall paintings, and 4) wall niches and architectural structures, while the concluding section will present a brief outline of composite structures which have been coined 'altar ensembles'. ${ }^{4}$

\section{RELIQUARIES AND TABERNACLES}

During the first centuries of Christianity, altars were closely connected to relics. In fact, the presence of relics in a cavity in the stipes or altar block de facto turned every altar into a reliquary. ${ }^{5}$ Reliquaries were also commonly placed on or behind the altar. This situation is now preserved only by way of exception. A rare and early survival of a reliquary in the form of an altar statue is preserved in the church of Sainte-Foy in Conques in southwest France. This statue, covered in precious metals, was created in the course of the ninth and tenth centuries. It is now kept in the church's treasury, but was certainly connected to the main altar of the church from the very beginning. How exactly is not known: did it rest immediately on the mensa or altar table or was it rather placed on a pedestal behind the altar? ${ }^{6}$

The famous precious shrine of the Three Kings in Cologne Cathedral stands on a modern pedestal at right angles behind the high altar. Originally, it was kept in a protective chest which stood in the same position. Around I200, the custom arose to open the front of the shrine on the feast day of the Three Kings in order to afford the faithful a view of the relics in its interior. ${ }^{7}$ A similar and better

${ }^{4}$ Cf. the seminal study by Verena Fuchß, Das Altarensemble. Eine Analyse des Kompositcharakters früh- und hochmittelalterlicher Altarausstattung (Weimar: VDG, 1999).

5 Cf. Joseph Braun S.J., Der christliche Altar in seiner geschichtlichen Entwicklung, 2 vols. (Munich: Widmann, 1924), vol. 2, p. 545.

${ }^{6}$ See: Le trésor de Conques: exposition du 2 novembre 2001 au II mars 2002, Musée du Louvre, eds. Danielle Gaborit-Chopin and Élisabeth Taburet-Delahaye (Paris: Éditions du patrimoine/Musée du Louvre, 200I). I would like to thank Dr Emanuel Garland from Toulouse for his information.

7 Cf. Joseph Hoster, 'Zur Form der Stirnseite des Dreikönigenschreins', in Miscellanea pro arte. Hermann Schnitzler zur Vollendung des 60. Lebensjahres am I3. Januar 1965 (Düsseldorf: Schwann, 1965), pp. 194-217. 
preserved arrangement can be seen in the church of St Severin in the same city. Here, a stone shrine with trellised sides holds a metal reliquary (restored) of the patron saint, resting on a pedestal consisting of four columns standing at right angles behind the altar, so that the faithful could obtain the virtus of the relics by passing underneath. ${ }^{8}$ In this case, the front of the shrine, which is one of the short sides, forms a backdrop to the altar ritual and thus assumes the function of a retable. In other cases, one of the long sides is turned towards the viewer. The shrine of Santa Eulalia in the crypt of Barcelona Cathedral, carved in 1339 by the Pisan sculptor Lupo di Francesco, is placed parallel to the back side of the mensa. ${ }^{9}$ The stretched front of the marble shrine, showing three scenes from the martyrdom of St Eulalia and surmounted by three standing figures, resembles the design of contemporary sculptured altarpieces.

With reliquaries functioning as retables, it is hardly surprising that the design of some altarpieces shows a close resemblance to contemporary reliquary shrines. An intriguing example is the early relic cabinet-cum-high altar retable in the church of the former Cistercian monastery at Loccum in northern Germany (Figure I). This mid-thirteenth-century cupboard follows the structure of many contemporary reliquary shrines, showing architectural characteristics, for example in the presence of gabled 'transepts' between slender pinnacles. The cabinet, which was heavily restored in the nineteenth century, consists of a double arcade of relic niches under a slanted roof, divided into two by three protruding 'transepts'. The niches were originally hidden behind moveable panels, which were removed only at high feasts to show the sacred objects. All of the reliquaries and probably also a Eucharistic vessel that were kept in the cabinet have vanished. ${ }^{\text {IO }}$

The Swedish art historian and restoration specialist Peter Tångeberg has pointed to the affinities between a number of early wooden altarpieces in Sweden and contemporary reliquary shrines. ${ }^{\text {II }}$ The early fourteenth-century wooden retable from Skattunge in Dalarna northwest of Stockholm shows close similarities to the late thirteenth-century shrine of Sint-Gertrudis in Nivelles/Nijvel near

${ }^{8}$ Clemens Kosch, Kölns romanische Kirchen. Architektur und Liturgie im Hochmittelalter (Regensburg: Schnell \& Steiner, 2000), pp. 52-55.

9 For a study of this object, see: Josep Bracons Clapés, 'Lupo di Francesco, mestre pisà, autor del sepulcre de santa Eulàlia', D’art, I9 (1993), pp. 43-5I.

Io See: Annegret Laabs, Malerei und Plastik im Zisterzienserorden. Zum Bildgebrauch zwischen sakralem Zeremoniell und Stiftermemoria I250-I430 (Petersberg: Michael Imhof, 200O), pp. 29-3I.

${ }^{\text {II }}$ Peter Tångeberg, 'Retables and Winged Altarpieces from the Fourteenth Century. Swedish Altar Decorations in their European Context', in The Altar and its Environment, IISO-I400, ed. by Justin E.A. Kroesen and Victor M. Schmidt (Turnhout: Brepols, 2009), pp. 223-40, here 23I-33. 
Brussels, in present-day Belgium, which was largely lost in I9I4. The Skattunge retable shows a horizontal row of saints' statues standing in niches which are fully developed in the round, with saddle roofs, flying buttresses and gables, as is also the case in the Nivelles reliquary. Furthermore, the front of the buttresses between the statues follows models adopted from works in precious metals, using gold and silver polychromy and imitation precious stones. A second retable of the same type, originally from Ala on the island of Gotland, is now in the Gotlands Museum at Visby.

A number of early winged retables from the first half of the fourteenth century are known to have functioned as relic cabinets, which induced Harald Keller to publish a much cited article in 1965 in which he explains the genesis of the genre entirely in terms of its function as a reliquary shrine. The moveable wings would have been added to prevent the sacred elements from suffering theft or damage. ${ }^{\mathrm{I} 2}$ Even if this view may be too monolithic and seems to be contradicted by the fact that many early winged retables were never used to store relics, it certainly holds true for a number of famous triptychs in northern Germany. The winged high altar retable in the former Cistercian abbey of Doberan in Mecklenburg dating from ca. 1300 was indeed used to hold the monastery's large relic collection. ${ }^{13}$ These reliquaries were placed inside the central chest of the retable, which is divided into two storeys, on both sides of a tall central niche which held a statue of the Virgin and Child that also served to store the consecrated Host. A second reliquary triptych is preserved in the former abbey church of Cismar, in Schleswig-Holstein. In this case, the central chest is divided into five tall niches, of which the back panels are all decorated with reliefs.

Only recently, the similarities between these early German winged altarpieces and contemporary Catalan shrine retables, the so-called 'tabernacles', have been observed. ${ }^{I 4}$ The high altar tabernacle from Barcelona Cathedral, now in the nearby church of St Jaume, was completed in 1366 . Written sources indicate that this structure not only housed a number of reliquaries, but also provided space for the

I2 'Der Flügelaltar als Reliquienschrein', in Studien zur Geschichte der europäischen Plastik. Festschrift Theodor Müller zum I9. April 1965, ed. by Kurt Martin et al. (Munich: Hirmer, 1965), pp. I25-44.

${ }^{13}$ See: Annegret Laabs, 'Das Hochaltarretabel in Doberan: Reliquienschrein und Sakramentstabernakel', Entstehung und Frühgeschichte des Flügelaltarschreins, ed. by Hartmut Krohm and Klaus Krüger (Wiesbaden: Reichert, 200I), pp. I43-56 and Johannes Voss and Jutta Brüdern, Das Münster zu Bad Doberan (Munich: Deutscher Kunstverlag, 2008), pp. 35-4I.

${ }^{14}$ Matthias Weniger, 'Doberan, Cismar - Tortosa', in Entstehung und Frühgeschichte (as note I3), pp. 193-204. 
monstrance containing the consecrated Host. ${ }^{15}$ Similar models are known from elsewhere in Catalonia, including Manresa, as well as on the island of Mallorca, in the cathedral at Palma. The most conspicuous difference between these 'tabernacles' and the early winged altarpieces in Germany is — in most cases — their strong vertical thrust and the absence of wings, in line with the general development of the Spanish medieval altar retable. ${ }^{16}$

Retables retained their function as relic cabinets until the very end of the Middle Ages — and even beyond. The high altar in the collegiate church (now cathedral) of St Victor at Xanten on the German Lower Rhine, which was created between 1529 and I533, was primarily designed as a repository for the church's extensive relic collection. The central chest and the predella contain a large number of cavities in which head reliquaries, relic busts and small box shrines centre on the precious shrine of St Victor, dating from the twelfth century. This cupboard can be closed off by means of a double pair of painted wings. ${ }^{17}$

A development related to the retable as a relic repository was the incorporation of the receptacle of the relic of all relics: the consecrated Host. The Eucharistic statue of the Virgin and Child in Doberan Abbey has already been mentioned, and the name 'tabernacle', given to the Catalan altar shrines, indeed seems to imply that the Host (in a pyx or a monstrance?) was also stored there. In I358, Bernat Roca signed a contract for a retable for the church of Sant Miquel in Catalan Cardona in quo ponetur sive recolligitur Corpus Nostri Domini Ihesu Christi ('in which should be placed or stored the Body of Our Lord Jesus Christ') ${ }^{18}$ During the second half of the fourteenth century, the custom of incorporating the Eucharistic tabernacle into the predella of the retable became widespread in Catalonia. Among the earliest surviving examples is the sculptured stone retable with protruding predella tabernacle in the church of Sant Llorenç in Lleida, erected by Bartomeu de Robió i Lleida and his workshop around 1390 (Fig. 7). ${ }^{19}$

is On this type, see: Francesca Español Bertrán, 'Tabernacle-Retables in the Kingdom of Aragón', in The Altar and its Environment (as note II), pp. 87-108.

${ }^{16}$ Exceptions are the horizontally shaped winged triptychs in the cathedral at Tortosa and the triptych from Piedra in Aragon, now in the Real Academia de Historia in Madrid, which, in their structure, show close similarities with the retables in Doberan and Cismar mentioned above.

${ }^{17}$ Described by Hans Peter Hilger, Der Dom zu Xanten (Königstein im Taunus: Langewiesche, I984), pp. I6-I7.

I8 Cf. Español Bertran, 'Tabernacle-Retables', pp. 9I-93.

19 Fragments of similar tabernacles from about the same period include examples from Albalate de Cinca, now in the Museu Nacional d'Art de Catalunya in Barcelona, and Vilafortuny, now in the Museu Frederic Marès in the same city. 
The oldest surviving retable containing a fixed tabernacle in Germany is the 'Klarenaltar' from $1350-60$, which was originally in the convent of the Poor Clares in Cologne and is now in the city's cathedral. ${ }^{20}$ Its protruding central section holds two superimposed niches, of which the lower, judging from the iconography of its door - the Mass of St Gregory, repainted in the early fifteenth century - served as a receptacle for the Host. In I424, a stone retable was erected in the church of St Martin in Landshut, Bavaria, showing an open niche in the lower section which communicates with a tower-shaped tabernacle protruding at the rear. ${ }^{2 \mathrm{I}} \mathrm{A}$ striking late fifteenth-century example is found in the village church of Jetsmark, in northern Jutland, Denmark (Fig. 2). Above the altar in the east wall of the chancel is a painted wall niche which serves as a retable and which holds a centrally placed wooden tabernacle with a wrought-iron grid in its front. Cases such as this, where architecture, wall painting and wood carving all merge into a retable-cum-tabernacle ensemble, may have been quite common in the late Middle Ages. However, because they are difficult to categorize, they have rarely found their way into our handbooks.

\section{ALTAR SCULPTURES AND IMAGE SHRINES}

A second category of altar decoration which is related to the retable but generally treated separately is the saint's statue sitting on the altar, such as the early medieval reliquary statue of Sainte-Foy at Conques discussed in the previous section. Such statues are often described in the literature as 'cult statues', although it remains rather unclear what this 'cult' actually entailed. ${ }^{22}$ Since almost all preserved cult statues have become detached from their original contexts, it is very difficult to establish to what extent this object type was common to medieval altars and how exactly these statues were connected to the altar.

An indication of how we should imagine this situation is provided by a number of miniatures in the Cantigas de Santa Maria ('Canticles of the Virgin'), a collection of Marian hymns which originated in central Spain around I260. Here, we see a statue of the enthroned Virgin Mary sitting directly on the altar

${ }^{20}$ See: Norbert Wolf, Deutsche Schnitzretabel des I4. Jahrhunderts (Berlin: Deutscher Verlag für Kunstwissenschaft, 2002), pp. 84-94.

${ }^{21}$ Braun, Der christliche Altar, vol. 2, pp. 627-29.

${ }^{22}$ This term was problematized by Hans Belting in Bild und Kult. Eine Geschichte des Bildes vor dem Zeitalter der Kunst (Munich: C.H. Beck, 1990). 
mensa. Similar arrangements can still be found in a number of country churches on the Swedish island of Gotland, for example in Bro, Väte, Tofta, Guldrupe and Träkumla, where they adorn one of the side altars. These Early Gothic sculptures provided a backdrop to the ritual celebrated on the altar mensa and thus functioned as retables. It is questionable, however, whether such unprotected and indeed even 'irreverent' arrangements are historically trustworthy. As a rule, sculptures placed on altars seem to have been provided with some sort of framework, for example in the shape of an aedicule shrine with or without shutters.

A first and simple category of framing takes the form of a back panel or dossal, providing a backdrop to the statue and thus also to the celebration of the Mass. A thirteenth-century pedestal and dossal from Högsrum on the Swedish island of Öland, now preserved in the Historiska Museet in Stockholm, must have provided a visual framework to a now lost sculpture. ${ }^{23}$ This combination of sculpture and dossal is reflected in an early stone retable from Carrières-sur Seine (formerly Carrières-Saint-Denis, Yvelines) now preserved in the Musée du Louvre in Paris, dating from the second quarter of the twelfth century. ${ }^{24}$ In the centre, the Virgin and Child are enthroned, while the sides show the Annunciation (left) and the Baptism in the Jordan (right). The Virgin is framed by an arched canopy resting on two round columns. Although the cresting of the canopy is part of a continuous frieze, the visual effect of the central projection suggests that the Marian image is placed under a separate ciborium. The depictions on the side sections provide a framework and narrative context to the core image which is the only frontally placed figure.

Another example of the combination of a cult image and a back panel is a mid-thirteenth-century retable from the church of Saint-Martin d'Envalls at Angoustrine in the French Pyrenees, now preserved in the Centre d'Art Sacré in L'Ille-sur-Têt (Pyrénées-Orientales) (Fig. 3). Here, the statue of the Sedes Sapientiae - which was lamentably stolen during the I970s —-was surmounted by a crenellated ciborium resting on round posts. A broad painted panel with projecting ends and a raised central section in the shape of a halo forms a dossal, in the original sense of 'back panel' to the sculpture in the shrine. Several authors have described this object as a triptych. However, the 'wings' cannot be moved,

${ }^{23}$ Peter Tångeberg, Holzskulptur und Altarschrein. Studien zu Form, Material und Technik (Munich: Callwey, 1989), p. 34.

${ }^{24}$ See: Pierre-Yves Le Pogam, 'Le retable de Carrières', in The Altar and its Environment (as note II), pp. I69-I82 and Les premiers retables (XII - début du XIV siècle). Une mise en scène du sacré [catalogue Musée du Louvre] (Paris: Musée du Louvre Éd, 2008), p. 34. 
and their size does not correspond to the sides of the canopy. The side sections feature representations of the Annunciation and Visitation, thus adding a modest narrative element. The fact that this remarkable ensemble was created in a small, remote country church suggests that this type of altar furnishing was rather current in Catalonia during the thirteenth century. ${ }^{25}$

The custom of placing altar sculptures inside architecturally shaped frames seems to have been quite widespread. These receptacles, in the form of an open ciborium, are generally referred to as 'tabernacle shrines'; the pedestal, rear wall and canopy are usually fixed, and many are equipped with painted or carved wings. ${ }^{26}$ By closing these shutters, the image could be protected and withdrawn from sight, to be revealed again during the liturgical ceremony. When opened, the tabernacle closely resembled a medieval triptych or polyptych. Contemporary depictions show that these tabernacles could either be placed immediately on the altar mensa or on a console in the rear wall.

The genre has not received the attention it deserves, especially in its relationship to the origins of the winged altarpiece. One reason for this might be that surviving examples are mainly found in Scandinavia, which distorts our picture of its European spread. While extremely rare elsewhere, more than a hundred tabernacle shrines are wholly or partly preserved in Sweden alone. ${ }^{27}$ The oldest shrine which is known to have been fitted with shutters (at least north of the Alps), dating from around I200, originates from Appuna (Östergötland) and is now preserved in the Historiska Museet in Stockholm. ${ }^{28}$ It consists of a pedestal supporting a sculpture of the Virgin and Child enthroned, in front of a back panel showing traces of hinges. An early example, preserved more or less in its original state and context, sits on the southern side altar in the village church at Dädesjö (Småland). This shrine dates from around the middle of the thirteenth century and contains a sculpture of the holy King Olaf enthroned; of the original polychromy on the wings, only traces remain.

${ }^{25}$ Cf. Justin E.A. Kroesen, Staging the Liturgy. The Medieval Altarpiece in the Iberian Peninsula (Louvain etc.: Peeters Publishers, 2009), pp. 47-48.

${ }^{26}$ A definition and characterization of the genre is offered by Klaus Krüger, Der frühe Bildkult des Franziskus in Italien. Gestalt und Funktionswandel des Tafelbildes im I3. und I4. Jahrhundert (Berlin: Mann Verlag, I992), pp. 17-20 and Tångeberg, Holzskulptur und Altarschrein (as note 23), pp. 32-4I.

${ }^{27}$ Cf. Tångeberg, 'Retables and Winged Altarpieces' (as note II), p. 225: 'The fact that they are so rare elsewhere, such as in Germany, is certainly a result of their being discarded and the sculptures placed without their surroundings in churches and museums'. The number was kindly provided to me by Peter Tångeberg.

${ }_{28}$ Tångeberg, Holzskulptur und Altarschrein (as note 23), p. 33. 
As Peter Tångeberg has rightly pointed out, the role of such image shrines in the genesis of the retable has traditionally been underestimated. In his view, many early winged altarpieces should be understood as 'a quantitative development of the tabernacle shrine: instead of there being one particular sculpture, there were several of them in a row' ${ }^{29}$ However, considering these image shrines merely as forerunners to the winged altarpiece would not do them full justice, since the genre remained common alongside the retable until the end of the Middle Ages. In Sweden, a fair number of shrines have remained in situ in the churches for which they were made. ${ }^{30}$ Examples include the Marian shrine in Skällvik (Östergötland) from I46o-8o, a St Olaf shrine at Överenhörna (Södermanland) from about 1500 and a shrine from Överselö (Södermanland), now in the Sörmlands Museum at Nyköping, dating from the last quarter of the fifteenth century. In the village churches at Vansö and Härad (Figure 4), both in Södermanland, two different Late Gothic shrines have even survived in the same church. In all cases, the shrines and their images remain, whereas the altars to which they belonged were demolished after the Reformation. In view of the large dimensions of some shrines, their impact on the church interior must have been considerable.

Examples of tabernacle shrines in other European countries as far apart as Italy, Norway, Switzerland, Slovakia, Denmark, France, Germany and Spain may serve as proof that the genre was not at all a Scandinavian 'Sonderform', but rather a pan-European affair. ${ }^{3 \mathrm{I}}$ An early and strikingly large example in Spain is the Marian shrine from Castildelgado in Castile, dating from about 1300 and now preserved in the Museu Frederic Marès in Barcelona (Fig. 5). ${ }^{32}$ The aediculeshaped shrine is crowned by a canopy with three pointed gables and has a height of more than two metres. The central figure of the Virgin has disappeared; the insides of the doors are decorated with twelve scenes from her life. The same museum also possesses a Late Gothic folding tabernacle shrine, which originates from the convent of the Poor Clares at Calabazanos near Palencia in Castile. ${ }^{33}$

29 Tångeberg, 'Retables and Winged Altarpieces' (as note II), p. 225.

30 Tångeberg, Holzskulptur und Altarschrein (as note 23), pp. I30-35.

${ }^{31}$ Klaus Krüger mentions a number of examples in his study of the iconography of St Francis in Italy in the twelfth and thirteenth centuries, see: Der frühe Bildkult (as note 26), pp. 17-24. See also: Claude Lapaire, 'Les retables à baldaquin gothiques', Zeitschrift für schweizerische Archäologie und Kunstgeschichte, 26 (1969), pp. I69-90.

${ }^{32}$ Cf. Francesca Español Bertrán and Joaquín Yarza Luaces, Catàleg d'escultura i pintura medievals [catalogue Museu Frederic Marès] (Barcelona: Ajuntament de Barcelona, 199I), pp. 393-94.

33 Español Bertrán and Yarza Luaces, Catàleg (as note 32), pp. I89-90. 
The sculpture of St Clare, which is possibly of Netherlandish origin, rests on a hexagonal pedestal and can be hidden from view by painted wooden shutters.

The Calabazanos shrine, when opened, shows a striking formal resemblance with the retable of Santa María la Blanca in the former Augustinian monastery church of Sant Joan de les Abadesses, in the Catalan Pyrenees. This altarpiece was carved in marble in 1343 by an unknown sculptor who was strongly influenced by Italian Gothic sculpture. The six narrow side sections, all crowned by triangular gables, are strongly reminiscent of the moveable wings of tabernacle shrines. Both the shrine from Calabazanos and the altarpiece at Sant Joan de les Abadesses served the same purpose, namely as pictorial decorations to their respective altars. This raises the question of why one would describe only the second object as an altar retable, and not designate the first as such.

\section{WALL PAINTINGS}

The liturgical and theological significance of the altar and the ritual that took place there could be emphasized visually by adding paintings to the surrounding walls and the apsidal vault. ${ }^{34}$ As a backdrop to the altar, these painted apses assumed the function of a large retable, before the altarpiece properly speaking came to fruition. In accordance with Romanesque tradition, these painted programmes often created a relationship between the earthly rite, celebrated at the altar, and the heavenly liturgy, represented in the apsidal vault by Christ, the Virgin and the angels.

Some of the most important concentrations of Romanesque painted apsidal programmes preserved in Europe are found in parts of Scandinavia, including Denmark and Gotland, as well as South Tirol and the Catalan Pyrenees. ${ }^{35}$ Many wall paintings from the latter region can now be admired in the Museu $\mathrm{Na}$ cional d'Art de Catalunya in Barcelona. ${ }^{36}$ Most Romanesque cycles follow similar schemes, showing a heavenly vision in the calotte and a row of earthly figures on the convex wall below. Such coherent painted programmes became much less

${ }^{34}$ See: Otto Demus and Max Hirmer, Romanische Wandmalerei (Munich: Hirmer, 1968).

${ }^{35}$ Literature: Ulla Haastrup and Robert Egevang, Danske kalkmalerier, 7 vols. (Copenhagen: Nationalmuseet, 1986-92); Bengt Söderberg, Gotländska Kalkmålningar I200-I40o (Visby: Föreningen Gotlands Fornvänner, 197I); Josef Weingartner, Die Kunstdenkmäler Südtirols, 2 vols., Innsbruck: Tyrolia, 1985-9I); Joan Sureda i Pons, La pintura romànica a Catalunya (Madrid: Alianza, 198I).

${ }^{36}$ See: Eduardo Carbonell i Esteller and Joan Sureda i Pons, Tesoros medievales del Museu Nacional d'Art de Catalunya (Barcelona/Madrid: Lunwerg, 1997). 
common in Gothic churches, but painted decorations on the chancel walls did not disappear altogether. Around 1340, in the village church at Brent Eleigh in Suffolk, England, a low rectangular field showing a Calvary group was painted on the rear wall behind the altar, underneath the east window, with further depictions on both sides. This raises the question of where the retable properly speaking begins and where it ends: should only the small field above the mensa be regarded as such, or should we consider it as part of a larger wall retable together with the flanking figures, or even including the large east window, which undoubtedly was of stained-glass?

While the main altar was usually freestanding so that it could be circumambulated by the priest, side altars were often placed with their back to a wall, a pillar or a partitioning element, such as the rood screen. ${ }^{37}$ These building elements provided a backdrop to the altars, which made them perfectly suitable for decorations in the shape of paintings and/or carvings. Around the mid-fourteenth century, above the southern side altar in the church of St Georg at Rhäzüns, in the Swiss canton of Graubünden, an image of St John the Baptist framed by a trefoil arch was painted directly on the wall surface above the mensa to serve as a retable. Around 1330, in the church of St Nikolai in Stralsund in northern Germany, a Crucifixion scene flanked by a row of standing figures was painted as a retable in a side chapel to the south side of the nave. However, such simple altar decorations are quite rare, probably because most examples have subsequently been replaced by more elaborate arrangements.

Some wall paintings serving as altar retables have a more elaborate structure, for example in a northern side chapel of the collegiate church of St Andreas in Cologne dedicated to Saints Lambert and Ursula. Here, the painted surface from around 1350 covers the entire east wall of the chapel above the altar mensa, so that it can be regarded as a monumental painted altar retable. ${ }^{38}$ The programme is composed of four layers or registers and narrates a number of scenes from the life of the Virgin. The upper field shows the Coronation of the Virgin surrounded by four angels, below are the Annunciation, Visitation and Nativity, beside them the Adoration of the Magi, while the field immediately above the mensa depicts the Crucifixion, with two donators, flanked by Sts Ursula, Peter, Andrew and Lambert. This lower register is crowned by a frieze of saints under a round-arched

37 On side altars in medieval churches, see: Justin E.A. Kroesen, Seitenaltäre in mittelalerlichen Kirchen. Standort-Raum-Liturgie (Regensburg: Schnell \& Steiner, 2010).

${ }^{8}$ Cf. Fuchß, Das Altarensemble (as note 4), pp. I78-80 and Kroesen, Seitenaltäre (as note 37), p. 63. 
arcade, which separates it from the upper storeys. Again, this raises the question of whether the whole structure is to be regarded as the retable - much larger than any known panel retable from the same period- or whether only the lower register should be regarded as such, which shows the usual Passion iconography, suitable to serve as a background to the Mass.

In larger churches composed of several aisles, side altars were usually placed on the west side of the separating pillars or columns. Although most examples have vanished, some of these pillars still carry part of the painted decorations which once functioned as retables. A number of the square Romanesque pillars in the former abbey church of St Albans, near London, feature painted saints inside architecturally shaped trefoil frames in Early Gothic style, each crowned by an image of the Crucifixion. These painted retables help to reconstruct the altar topography before the Reformation, when all altars were demolished. ${ }^{39}$ In the above-mentioned church of St Nikolai in Stralsund, the fourth pillar from the west in the northern arcade shows a painted depiction of the Crucifixion above the Annunciation scene flanked by St Peter and St Paul which originated in about the mid-fourteenth century. The opposite column on the south side shows a painted predella with an angel on either side of a closed tabernacle surmounted by a standing depiction of the Virgin and Child receiving the Holy Spirit, beneath Christ as the Salvator Mundi (Fig. 6). Both painted pillars once served as retables to two side altars standing underneath which vanished after the Lutheran Reformation. ${ }^{40}$

Another area in the interior of medieval churches where side altars were commonly erected was the boundary between the chancel and nave. The perfectly oriented west side of the chancel screen provided a suitable background for one or more side altars and thus often assumed the function of a retable. A rare survival in England is the painted chancel screen in the village church at Ranworth, Norfolk, dating from around I500. The blind panelling in the side sections of this screen, covering the lower part of the transversal wall which separates the nave and chancel, was treated as an altar retable. ${ }^{4 \mathrm{I}}$ On the north side we see the standing figures of St Etheldreda, St Agnes, St John the Baptist and St Barbara,

39 Paul Binski, 'The Murals in the Nave of St Albans Abbey', in Church and City I000-I50o. Essays in Honour of Christopher Brooke, ed. by David Abulafia et al. (Cambridge: Cambridge University Press, 1992), pp. 249-78.

$4^{\circ}$ Kroesen, Seitenaltäre (as note 37), pp. 46-47.

${ }^{41}$ Kroesen, Seitenaltäre (as note 37), p. 82 and Justin E.A. Kroesen and Regnerus Steensma, The Interior of the Medieval Village Church (Louvain etc.: Peeters Publishers, 2012), pp. 58, I88. 
and on the south side St Mary Salome, the Virgin with Christ, St Mary Cleophas with four children and St Margaret of Antioch. All of the figures are crowned by little angels. The stone rood screen in the village church of Tiefenbronn, in south German Baden-Württemberg, has vanished, but the wall retables that were painted underneath its arches around I400 were rediscovered in I89I. Since their restoration in 1976-77, four lancet-shaped painted retables can again be seen on the east wall of the nave. The southernmost one is hidden behind a painted wooden altar chest. ${ }^{42}$

\section{WALL NICHES AND ARCHITECTURAL STRUCTURES}

Many side altars were framed or marked by niches in the rear wall. The inner surface of these recesses could be painted and objects could be placed inside them, implying a certain amount of overlap with the above-mentioned categories of wall paintings and altar sculptures. To my knowledge, nowhere has the combination of altar, niche and statue survived entirely intact; however, instances of partial preservation enable certain reconstructions to be drawn. Wall niches were especially common above and behind the side altars in Romanesque and Early Gothic country churches in northwestern Europe, where they usually stood in front of the east wall of the nave, on either side of the chancel arch. This seems to have been the classic pattern in village churches in Scandinavia, England and large parts of Germany, which usually boasted three altars.

In the village church at Norwegian Byneset near Trondheim the wide roundarched Romanesque altar niches were equipped with small windows in the rear walls, probably to allow light to shine on the mensa and/or the altar statues. ${ }^{43}$ Figurative paintings added to the niches sometimes show the altar's dedication which stands (or stood) beneath. Contemporary paintings are preserved in Romanesque altar niches in the village churches of Danish Måløv, near Copenhagen, and in Swedish Mästerby, on Gotland. Both niches show the Virgin and Child —in Måløv as a half-figure and in Mästerby enthroned between two angels - which indicates that the northern side altar was dedicated to the Mother of God, as was customary in medieval churches. In Måløv, the southern niche shows an unidentified, standing bishop. In the village church at Hauxton in

${ }^{42}$ Cf. Kroesen and Steensma, The Interior of the Medieval Village Church (as note 4I), p. 68.

${ }^{43}$ For this and other Norwegian examples, see: Øystein Ekroll and Morten Stige, Kirker $i$ Norge. Middelalder i stein (Oslo: Arfo, 200o). 
Cambridgeshire, England, an Early Gothic wall niche in the same position features a portrait of the standing St Thomas Becket, painted around I230. A beautifully painted Early Gothic crucifixion in the southern altar niche in the church of St Viktor in Schwerte in German Westphalia seems to make a more general reference to the sacrificial character of the Mass.

Today, sculptures preserved inside medieval altar niches are only seldom found. In the village church at Mære near Trondheim in Norway, both niche and figure have survived, but the altar was demolished after the Reformation. The niche, in the east wall of the nave to the north of the triumphal arch, reveals traces of paintings that once provided a backdrop for an early thirteenth-century Virgin and Child enthroned, which is now kept at the Vitenskapsmuseet in Trondheim. ${ }^{44}$ A largely reconstructed example of an altar sculpture inside a wall niche is the so-called 'Marian retable' from about II6o, found in the Cathedral of Erfurt in German Thuringia. ${ }^{45}$ Here, a sculpture of the Virgin and Child enthroned are placed in a small wall niche framed by figurative reliefs in stucco. From the top down, eight female martyrs, two holy bishops and a blessing Christ are represented. The sculpture and wall reliefs were originally polychromed and partly coated with precious stones. Sculpture, niche and framing are now in the southern side aisle, but originally they were probably situated in the chapel of St Michael, on the upper storey of the northern chancel tower. ${ }^{46}$

In some churches, including St Marien in Salzwedel in German Saxony-Anhalt and the village church in Björke on Swedish Gotland, the altar niches rise up high above the altars, which visually emphasizes these fixtures within the church interior. ${ }^{47}$ In the village church at Vamlingbo on Gotland, the semicircular shape of both high-rising altar niches in the east wall of the nave suggests that these should be regarded as echoes of Romanesque absidioles. In the southern transept chapel in the village church of Patrington in Yorkshire, England, a plain rectangular panel reredos sits between the altar mensa and three wall niches above. The entire structure originated in the second half of the fourteenth century. ${ }^{48}$ In cases such as these, one could ask, what precisely constitutes the retable and what not: is it only the panel immediately above the mensa, or rather the entire structure of

44 Ekroll and Stige, Kirker i Norge (as note 43), p. 244.

${ }^{45}$ Analysed in Fuchß, Das Altarensemble (as note 4), p. I09.

${ }^{46}$ Cf. Fuchß, Das Altarensemble (as note 4), p. IIo.

47 In both cases, the altars vanished at the time of the Reformation.

${ }^{48}$ Kroesen, Seitenaltäre (as note 37), p. 94. The reredos has lost its painted decorations and two of the three niches are now missing their sculptures. 
panel and niches? One could even argue that the architecture of the whole chapel serves as a retable to the altar, incorporating sculpted capitals and keystones and probably vault paintings, as well as stained-glass windows. In such cases, the 'altarpiece' would become part of the architecture of the church building as much as an aspect of its furnishings.

A number of altar retables are integrated into the architecture of the church building to such an extent that both have become practically indistinguishable. In England, a small number of so-called 'altar screens' are preserved, for example in Winchester Cathedral and the former abbey church at St Albans. ${ }^{49}$ In both cases, these monumental altarpieces also served to separate the high altar from the hustle and bustle around saints' tombs in the east ends, in these cases those of St Swithun and St Albans, respectively. Similar solutions were sometimes adopted at side altars. In the village church of North Leach, in Gloucestershire, in the second half of the fifteenth century, a partitioning wall was built in the southern side aisle to screen off the Lady Chapel behind it and at the same time serve as a backdrop to a side altar. The west side of this partition was treated in the manner of a wall retable featuring two superimposed rows of standing figures whose imprints can still be clearly recognized. Regarding these structures as altarpieces would quite dramatically change the English retable landscape, which is usually said to have vanished almost completely. Furthermore, the English altar screens are the only artistic genre comparable to the imposing Iberian retablo, which usually filled the entire wall surface of the church..$^{\circ}$

In Spain, from the late fourteenth century onwards, a specific type of altarpiece emerged which can be characterized as a 'wall retable'. The best examples, carved and gilded in the Late Gothic style, include the altarpieces in the cathedrals at Toledo, Seville, Oviedo and Ourense, to which can be added the cathedral of Coimbra in Portugal. ${ }^{5 \mathrm{I}}$ Forerunners to this distinct retable type were created in the Kingdom of Aragon (which also included Catalonia) during the second half of the fourteenth century. Some of these early Aragonese wall retables can be described as 'partitioning walls turned into altar retables'. In the church of Sant Llorenç in Catalan Lleida, the semicircular apse of the Romanesque church

49 The saints' statues, which had been removed at the time of the Reformation, were replaced by new ones during the nineteenth century.

so On this retable type, see: Judith Berg Sobré, Behind the Altar Table. The Development of the Painted Retable in Spain, I350-I500 (Columbia MO: University of Missouri Press, 1989), and Kroesen, Staging the Liturgy (as note 25).

5I See: Kroesen, Staging the Liturgy (as note 25), passim. 
was screened off in the last decade of the fourteenth century by the above-mentioned stone retable carved by Bartomeu de Robió i Lleida (Fig. 7). The small apsidal space behind the altar functioned as a sacristy for the storage of utensils used in the liturgy. In Tarragona Cathedral, the apse was also turned into a sacristy around I430, screened off by a huge stone retable created by Pere Joan de Vallfogona. ${ }^{52}$ This monumental altar retable, of proportions never seen before in Europe, was even extended on both sides by two flanking arched doors. ${ }^{53}$ In the Iberian Peninsula, it could be argued, during the late Middle Ages the relationship between altarpiece and architecture was almost turned around: the retable passed from being an element in the interior of the church to becoming part of it, and even making its mark on the entire space.

\section{COMPOSITE ALTAR ENSEMBLES}

Thus far, we have discussed a number of formal categories in relationship to medieval altars, including reliquaries and tabernacles, altar sculptures and image shrines, wall paintings and wall niches and architectural contexts. However, the classification of altar furnishings into clearly defined categories of object types is problematic, since many altars were equipped with a combination of different elements. Such composite and often layered configurations will be termed 'altar ensembles'. ${ }^{54}$

The composite character of many medieval altar furnishings is beautifully illustrated by a number of reconstruction drawings made by the French nineteenthcentury architect and historian Eugène Viollet-le-Duc. ${ }^{55}$ His reconstructions of high medieval altar decorations in French cathedrals and abbey churches often show the combination of a horizontal panel retable placed immediately on the altar with an open shrine on top housing a sculpture or reliquary. The arrangement of the altar, retable, pedestal and aedicule with a reliquary shrine in the chapel of la Vierge Blanche in Saint-Denis abbey church near Paris was reconstructed according to Viollet-le-Duc's drawing (Fig. 8). Similar configurations preserved in

52 This apse also included an integrated Eucharistic tabernacle at the rear of the retable.

53 Similar transversal walls-cum-altar retables are known from other Catalan cathedrals, including Vic and Lleida, see: Kroesen, Staging the Liturgy (as note 25), pp. 77-78.

${ }_{44}$ Following the study by Verena Fuchß, Das Altarensemble (as note 4).

"See: 'Autel' in Eugène Viollet-le-Duc, Dictionnaire raisonné de l'architecture française du XI au $X V t^{e}$ siècle, Io vols. (Paris: Morel, $1874-76$ ). 
churches are very rare, but some examples can be mentioned. In the church of St Dymphna in Geel, Belgium, the high altar carries a low, Late Gothic winged retable which supports the front side of an open aedicule placed at right angles, designed to hold the relic shrine of the local patron saint. The ensemble is crowned by a Calvary Group. Behind the altar, in the ambulatory, this shrine rests on a stone structure in the form of a Gothic ciborium. In cases such as this, the question could be asked: what exactly is the retable? Is it just the carved triptych or does it also include the aedicule at the top? Or should the entire arrangement be described as the multiform 'altarpiece', including even the ciborium pedestal at the back? In cases such as these the term 'altar ensemble' seems more suitable to describe its essentially composite character.

Vestiges in the country church at Hall on Swedish Gotland allow for a conjectural reconstruction of an ensemble structurally similar to the Viollet-le-Duc drawings. North of the chancel arch, at a height of approximately I.20 metres, the Coronation of the Virgin, between angels with censers and surrounded by a rectangular frame, was painted on the wall in the first half of the fourteenth century (Fig. 9a). These paintings, which continue on the north wall in the form of a row of individual saints, served as a retable to a side altar. ${ }^{56}$ Above the eastern section, a sturdy stone console projects from the middle of the wall. In relation to the iconography of the paintings below, it must have served to support a Marian sculpture, whether or not in a shrine (Fig. 9b). In spite of its humble materials, the Hall ensemble possessed an undeniable degree of monumentality. The decoration of this side altar corresponds to a basic pattern of medieval altar furnishing, consisting of a rectangular field immediately above the altar mensa, crowned by an individual effigy in a shrine-like receptacle. What would constitute the retable in this case? Is it only the painted 'panel' on the east wall, or would it include the figures on the north wall? One would rather describe the composite whole as an altar ensemble, which also encompasses the enshrined statue.

The composite nature of much late medieval altar furnishing is reflected in contemporary imagery (miniatures, paintings, engravings and woodcuts) of altars in churches, which quite often show a horizontal panel retable combined with a tabernacle shrine on top. ${ }^{57}$ There is a notable discrepancy between such

${ }^{56}$ Justin E.A. Kroesen, 'Seitenaltäre im Mittelpunkt. Beispiele aus den mittelalterlichen Kirchen der Insel Gotland (Schweden)', Das Münster, 64/I (2010), pp. 282-94, here 291.

57 See Anja Sibylle Steinmetz, Das Altarretabel in der altniederländischen Malerei. Untersuchungen zur Darstellung eines sakralen Requisits vom frühen I5. bis zum späten I6. Jahrhundert (Weimar: VDG, 1995). 
representations and the stock of extant medieval altar furnishings, mostly consisting of winged retables. ${ }^{58}$ The Triptych of the Seven Sacraments by Rogier van der Weyden, now in the Museum voor Schone Kunsten in Antwerp, was commissioned in I44I by Jean Chevrot, bishop of Tournai, for the altar in his private chapel. On the altar before the chancel screen in the church interior depicted is a low panel retable with a projecting central section, on which an opened image shrine with folding shutters rests (Figure Io). Van der Weyden's Exhumation of St Hubert from around I440, painted for the chapel of the same name in the church of Sint-Goedele in Brussels and now in the National Gallery in London, also features an ensemble of retable and shrine, which is here combined with an embroidered antependium and a precious reliquary on the mensa.

A similar composition is found on a retable panel from around 1460 from the Benedictine church of Sopetrán (now a ruin) near Guadalajara in Castile (Spain), preserved in the Museo del Prado in Madrid. Here, we see the benefactor Enrique kneeling before an altar in a monastery church. On the altar, whose front is covered with an embroidered antependium, is a panel retable of the same type as in Van der Weyden's paintings, crowned by an open image shrine with painted wings. ${ }^{59}$ Another intriguing example is depicted on the previously discussed image shrine from Calabazanos. In this case, the paintings on the shrine itself reveal how similar shrines were originally situated on the altar: the panel at the bottomright features St Clare kneeling before an altar in a small chapel, while her hair is being cut by St Francis. On the altar is a low panel retable with a projecting centre, and on top is an opened image shrine. The fact that most of the examples mentioned originate from the Low Countries, or from regions under strong Netherlandish influence, suggests that such composite altar ensembles were fairly common in the late medieval churches of northwest Europe.

${ }^{58}$ It should be mentioned here that in central and northern Europe, wingless retables were much more common during the late Middle Ages than is often assumed. Wings are absent, for example, in most stone retables, of which many examples survive in central and northern France and in eastern Germany.

59 The similarity to the work of Van der Weyden and other Southern Netherlanders suggests that the panel was painted by a Netherlandish artist in Spain, or by a Spaniard influenced by the art of the Southern Netherlands. 
CONCLUSION

To conclude, the question should be raised once more: what defines a medieval altar retable? This article has shown that a clear-cut definition cannot be formulated. A broad approach is to be preferred over a narrow one, whereby configurations that currently do not appear in art historical handbooks are also included. This more encompassing approach is automatically implied when we start looking at altar retables from a functional perspective, according to a working definition provided in the first section: 'any object or depiction on top of or behind the altar that forms a backdrop to liturgical activity on and around the altar'. When the altar retable is defined functionally a number of observations can be made:

I) The relationship between reliquary and retable has not as yet been explored. Reliquaries could assume the function of an altar retable, while retables, in turn, sometimes functioned as relic holders.

2) Many altars had sculptures of individual saints placed on their slabs. Especially when these effigies are enshrined with folding shutters, the opened state closely resembles a medieval triptych or polyptych.

3) Many paintings found on walls and pillars in medieval churches served as retables to altars which have mostly vanished. Such paintings should be studied anew in their functional context.

4) Correspondingly, the walls behind many altars were treated in the manner of a retable, articulated with niches and other framing elements. Such situations problematize the distinction between retable and architecture.

5) Many medieval altar decorations display a fundamentally composite character. Clear distinctions between formal categories such as frontals, altar sculptures, panel retables, tabernacles and shrines are sometimes very difficult to maintain.

To gain a better insight into the true variety of medieval altar decorations, special attention should be paid to side altars. This element in medieval church interiors should not be viewed as a mere derivative of the main altar, but as a category in its own right, with its own development and dynamics. ${ }^{60}$ Many of

${ }^{60}$ It is noticeable how little is known on the actual use of side altars in the liturgy. They were most probably only used on particular feast days as well as for Requiem Masses said on pre-established dates; the rest of the year, their primary function may have been that of a shrine or pedestal, and thus a stage for devotion. 
the examples discussed in the preceding sections are found in the context of side altars rather than high altars. These altars were often placed with their back to walls and pillars, which in turn assumed the role of a backdrop, offering a wide range of decorative opportunities, in the form of paintings and carvings, as well as the placement of different objects and images. Re-evaluating the side altar as a basic element of the medieval church interior would enable us to form a more realistic picture of the variety of medieval altar furnishings and to better understand the original spatial context of the many objects we now admire in museums. Furthermore, studying these hitherto understudied altar decorations - their design, composition and iconography — in close relationship to the rituals associated with them, will provide us with a more comprehensive picture of the medieval Mass and its meanings.

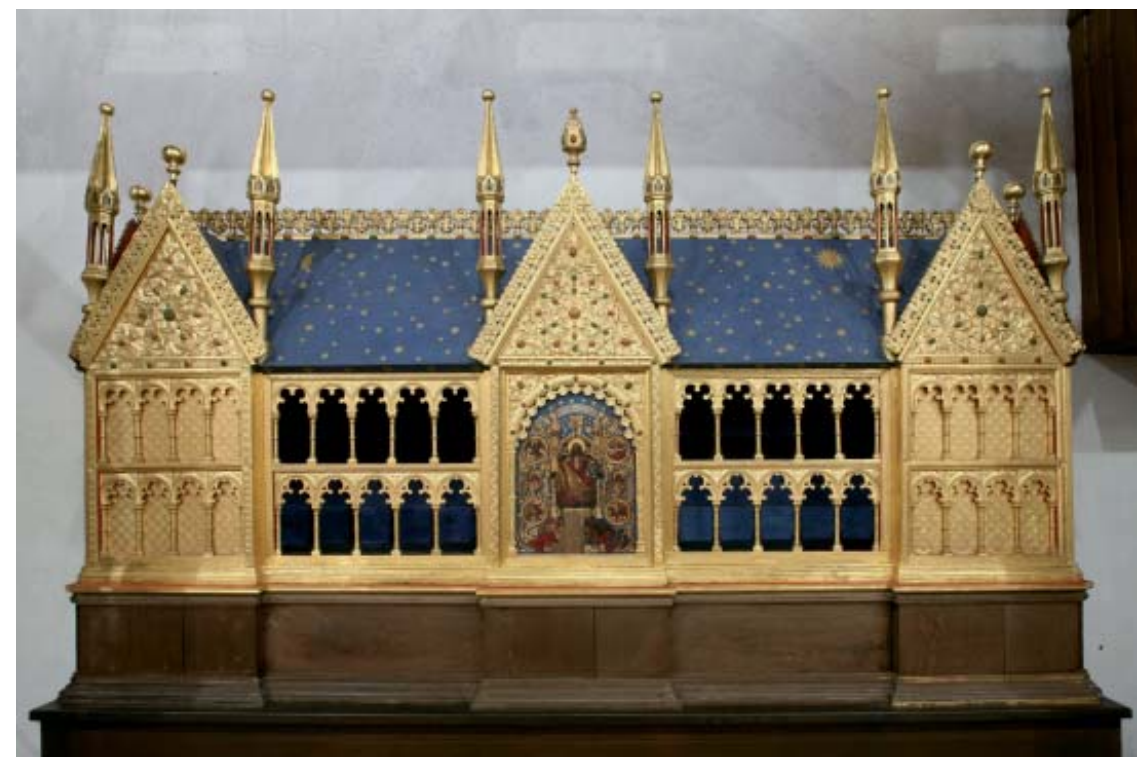

Fig. I. Loccum (Germany), former monastery, relic cabinet-cum-altar retable, $c a$. I250 [photo Justin Kroesen and Regnerus Steensma]. 


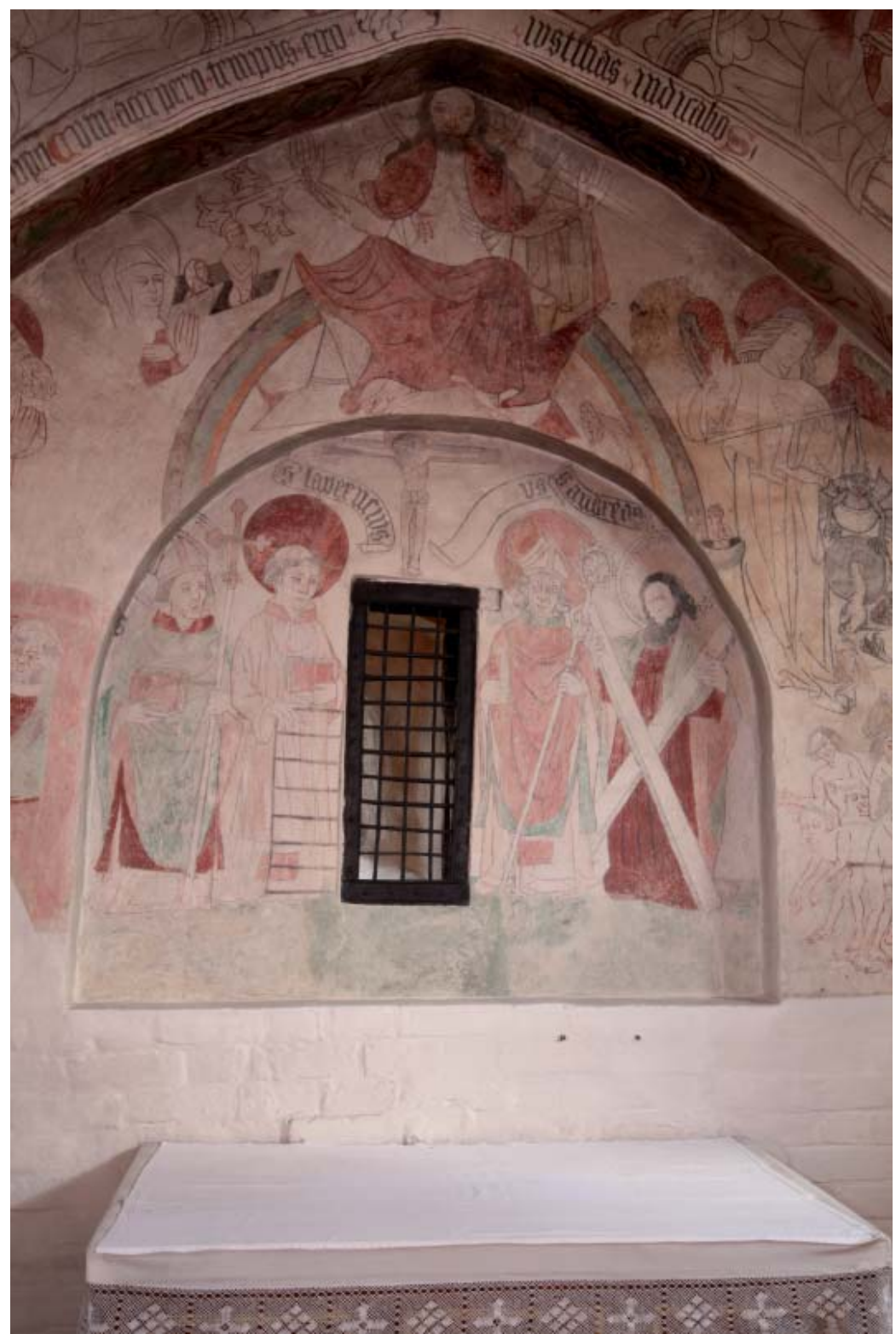

Fig. 2. Jetsmark (Denmark), village church, altar decorations, second half of the $\mathrm{I}^{\text {th }}$ century [photo Justin Kroesen]. 


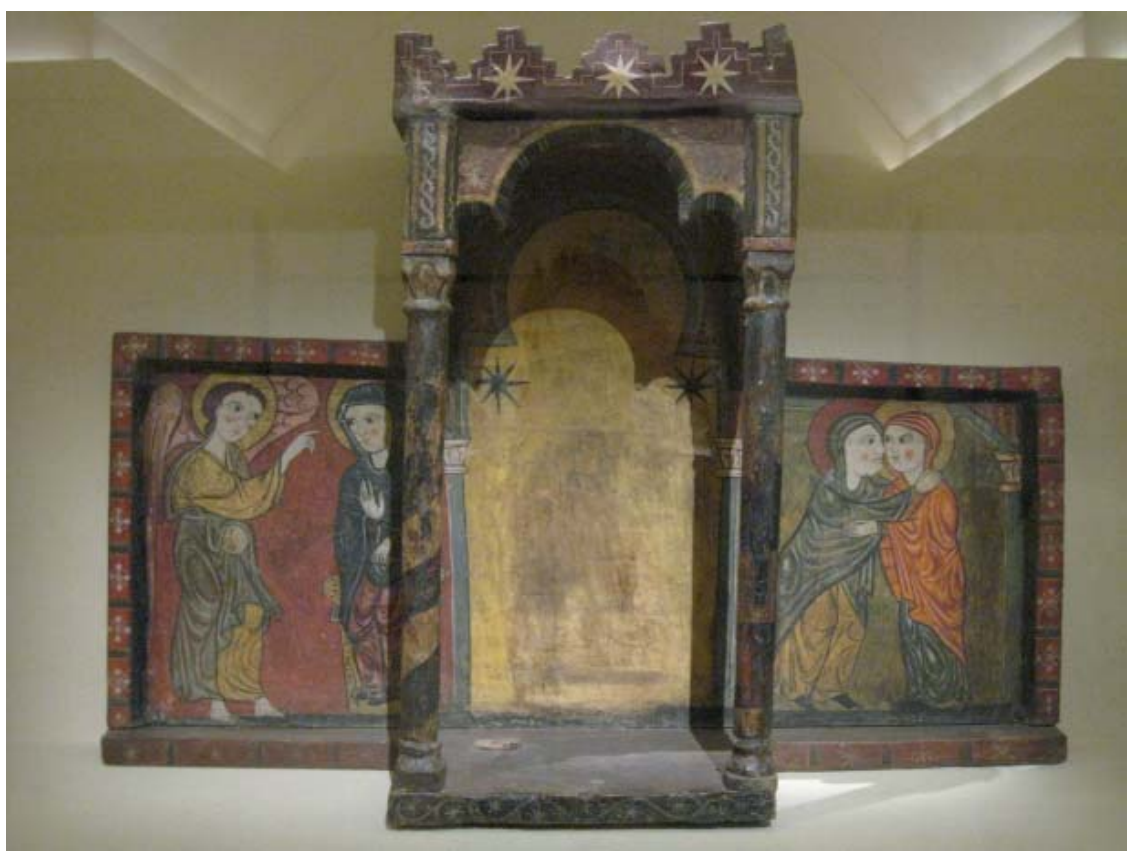

Fig. 3. L'Ille-sur-Têt (France), Centre d'Art Sacré, retable from Saint-Martin d'Envalls in Angoustrine, $c a$. 1250 [photo Justin Kroesen]. 


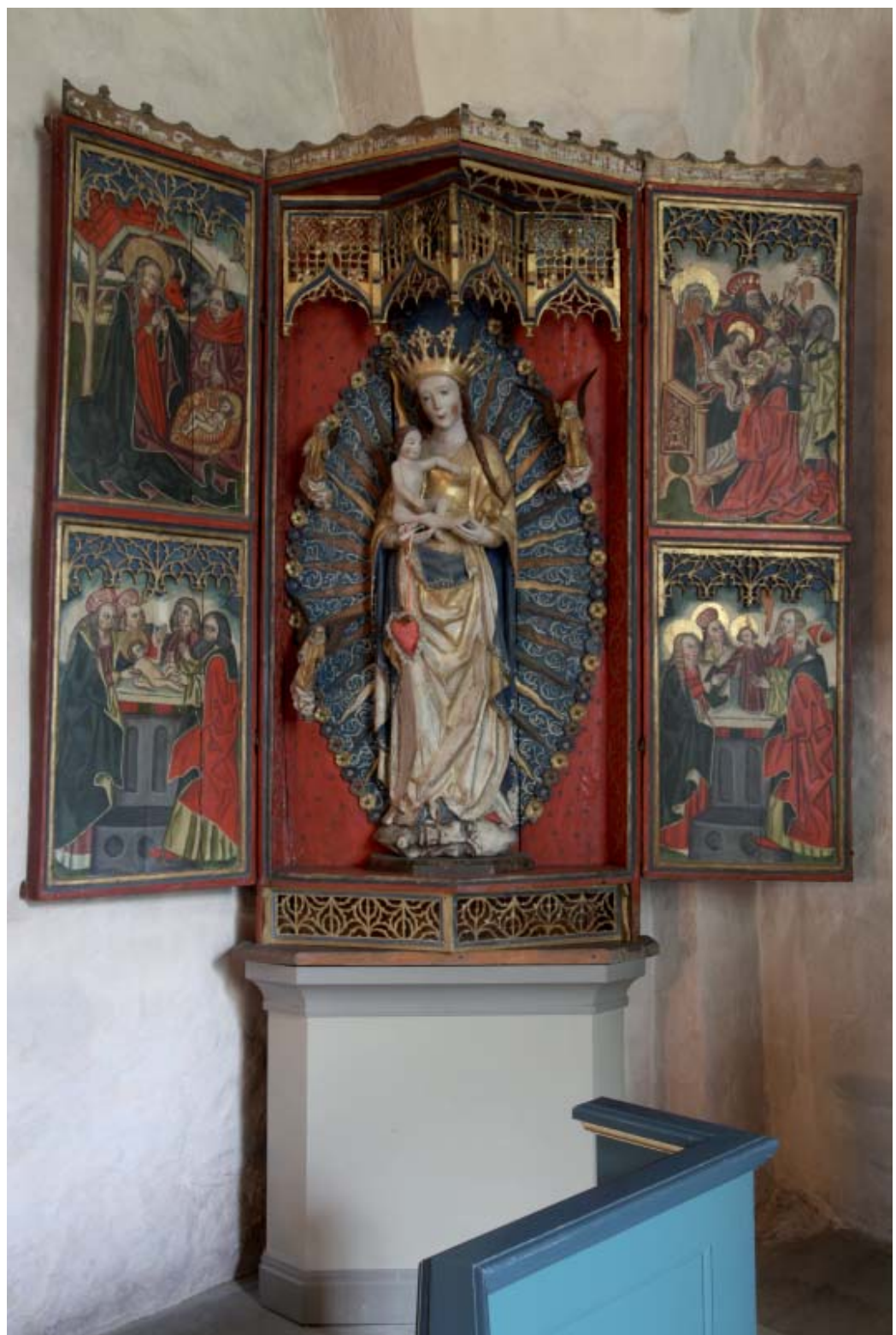

Fig. 4. Härad (Sweden), village church, tabernacle shrine, $15^{\text {th }}$ century [photo Justin Kroesen]. 


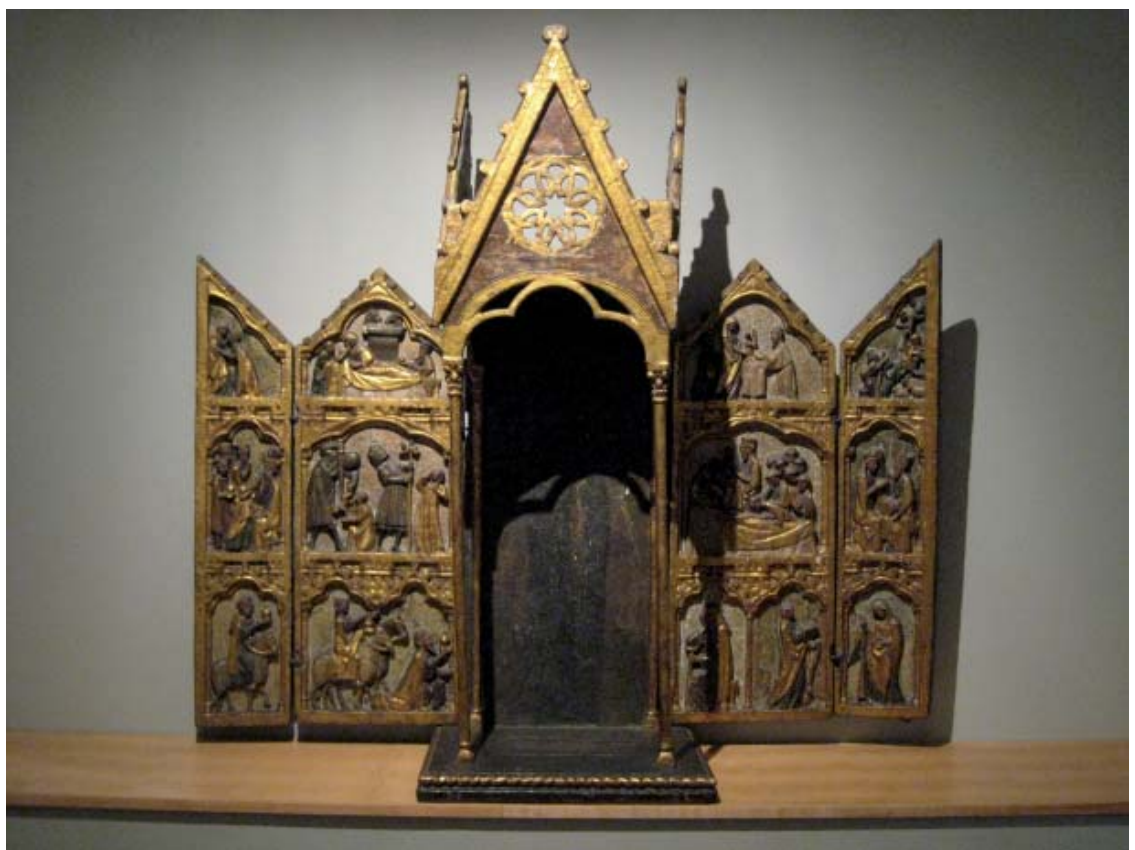

Fig. 5. Barcelona (Spain), Museu Frederic Marès, tabernacle shrine from Castildelgado, ca. I300 [photo Justin Kroesen]. 


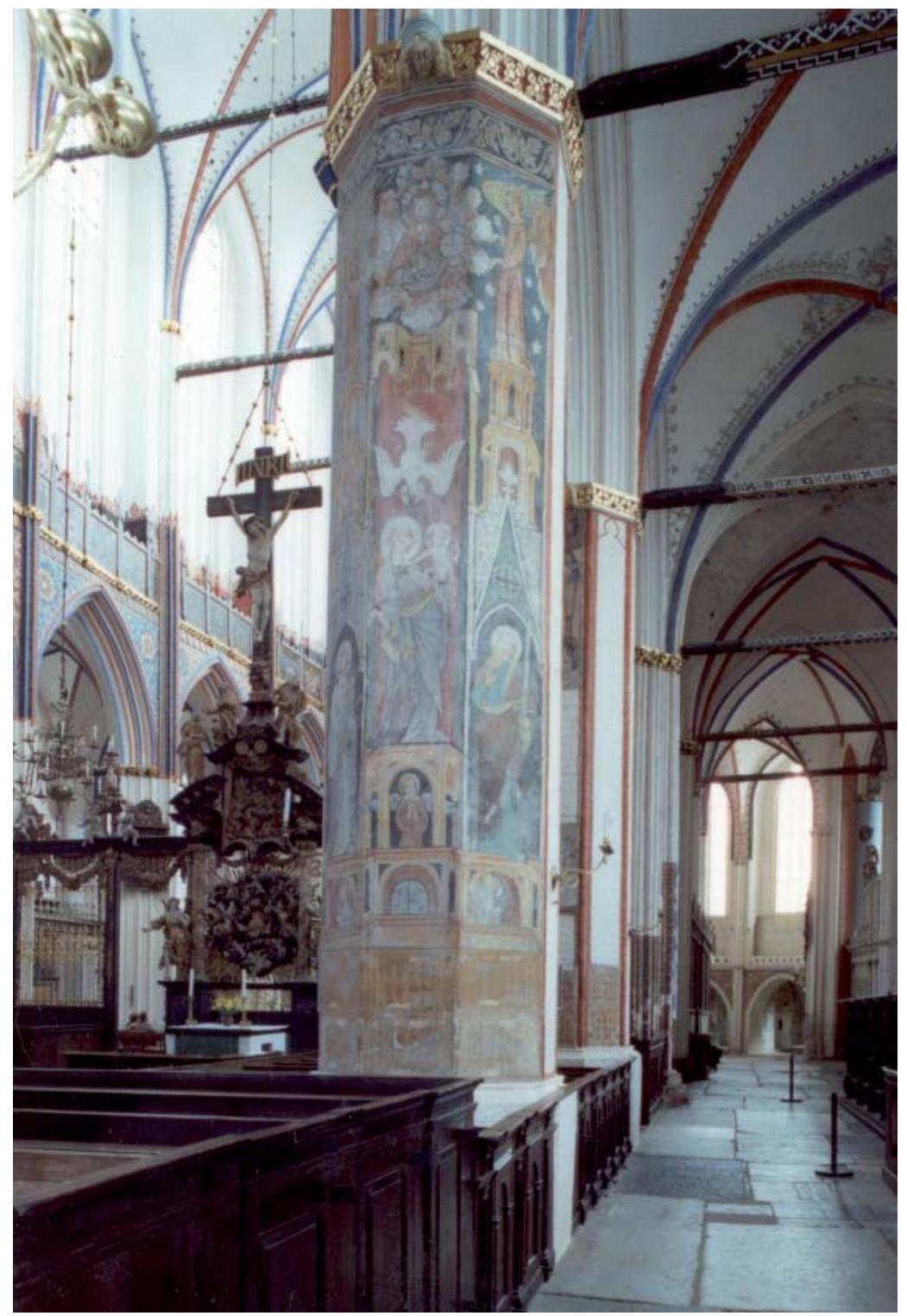

Fig. 6. Stralsund (Germany), St Nikolai, painted pillar on the south side of the nave, $c a$. 1350 [photo Justin Kroesen and Regnerus Steensma]. 


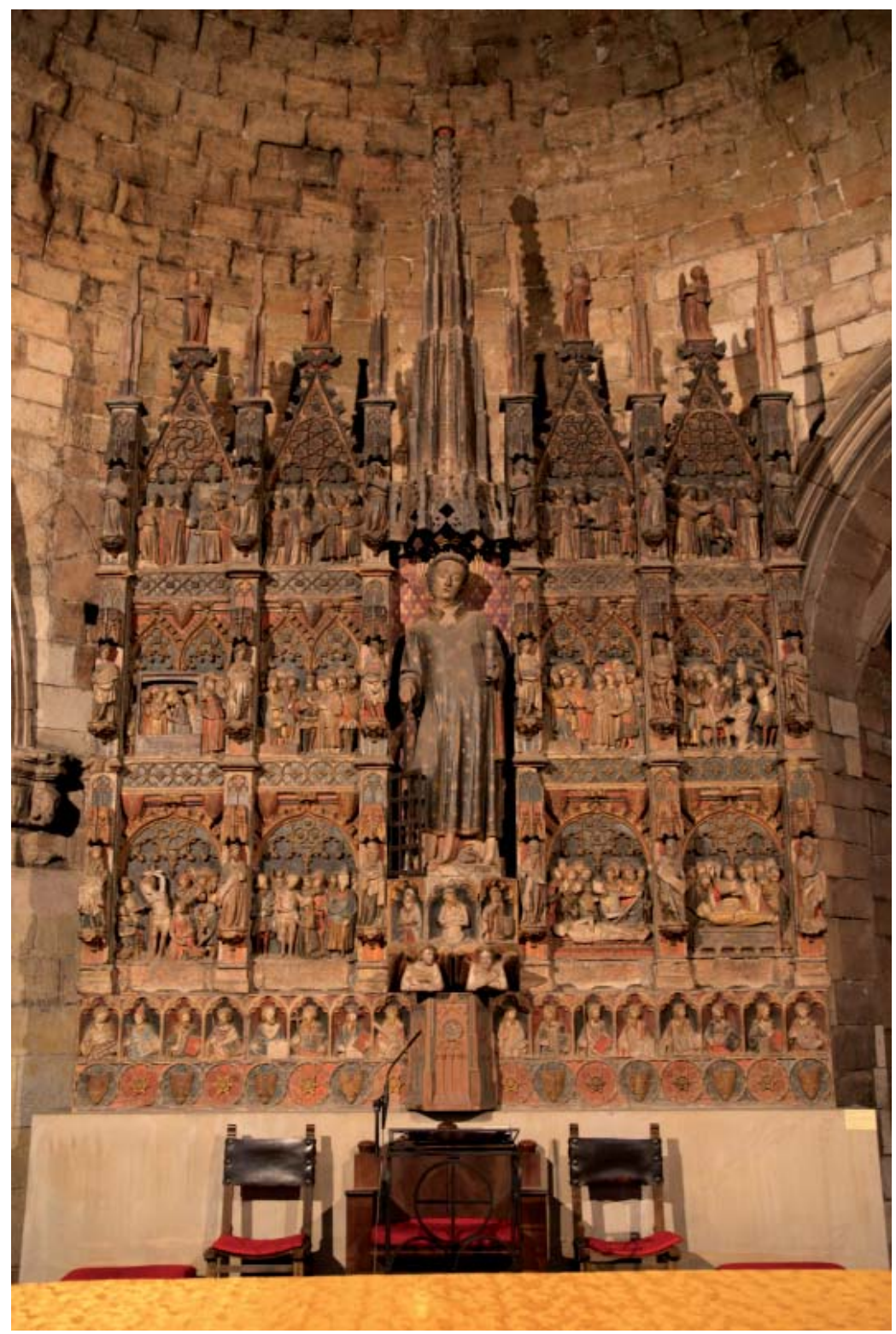

Fig. 7. Lleida (Spain), Sant Llorenç, high altar retable, $c a .1390$ [photo Justin Kroesen]. 


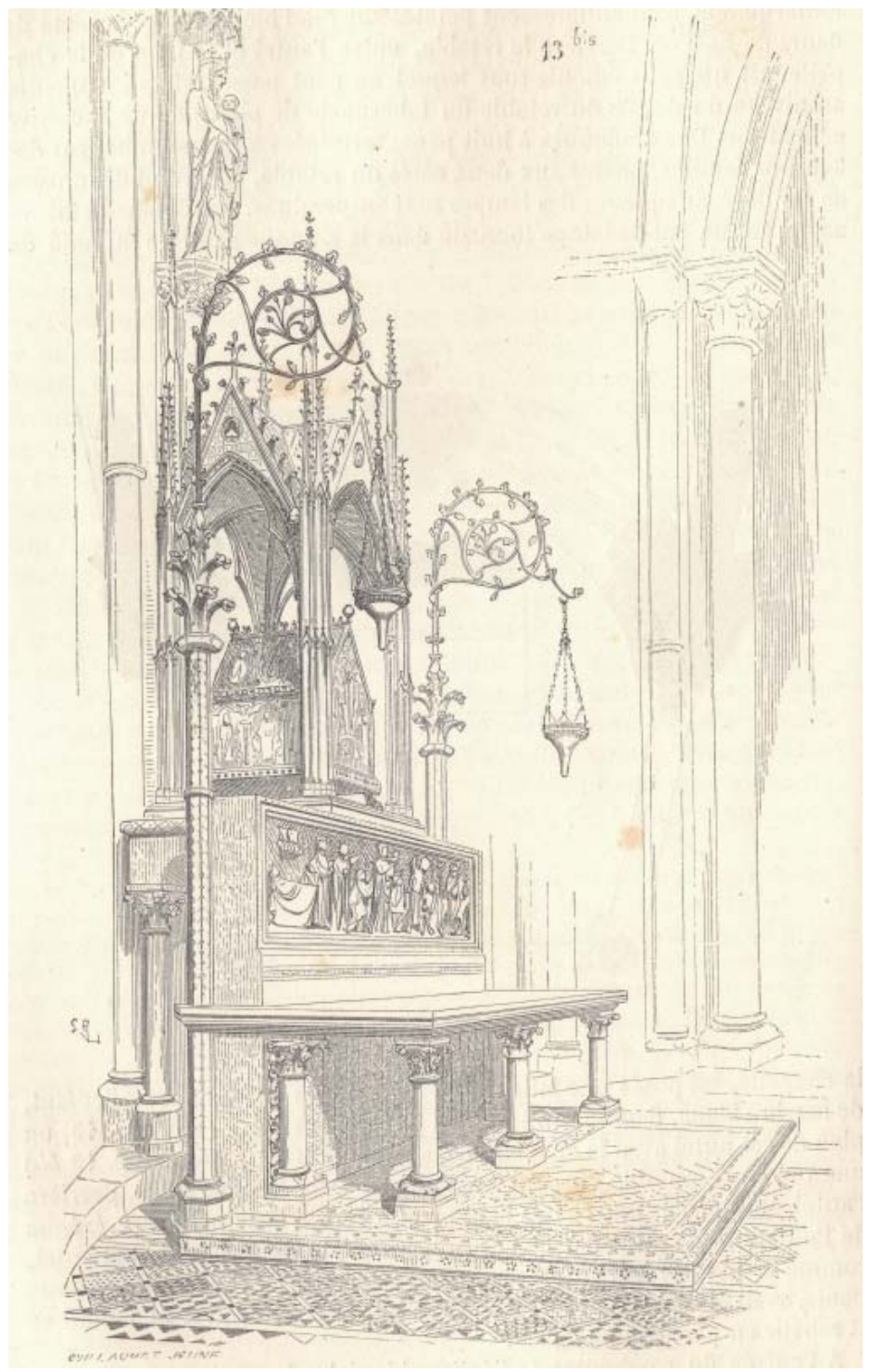

Fig. 8. Saint-Denis (France), former abbey, reconstruction of the $3^{\text {th }}$-century altar ensemble in the chapel of La Vierge Blanche by Eugène Viollet-le-Duc

[after his Dictionnaire raisonné de l'architecture française $d u X I^{e}$ au XVI siècle]. 


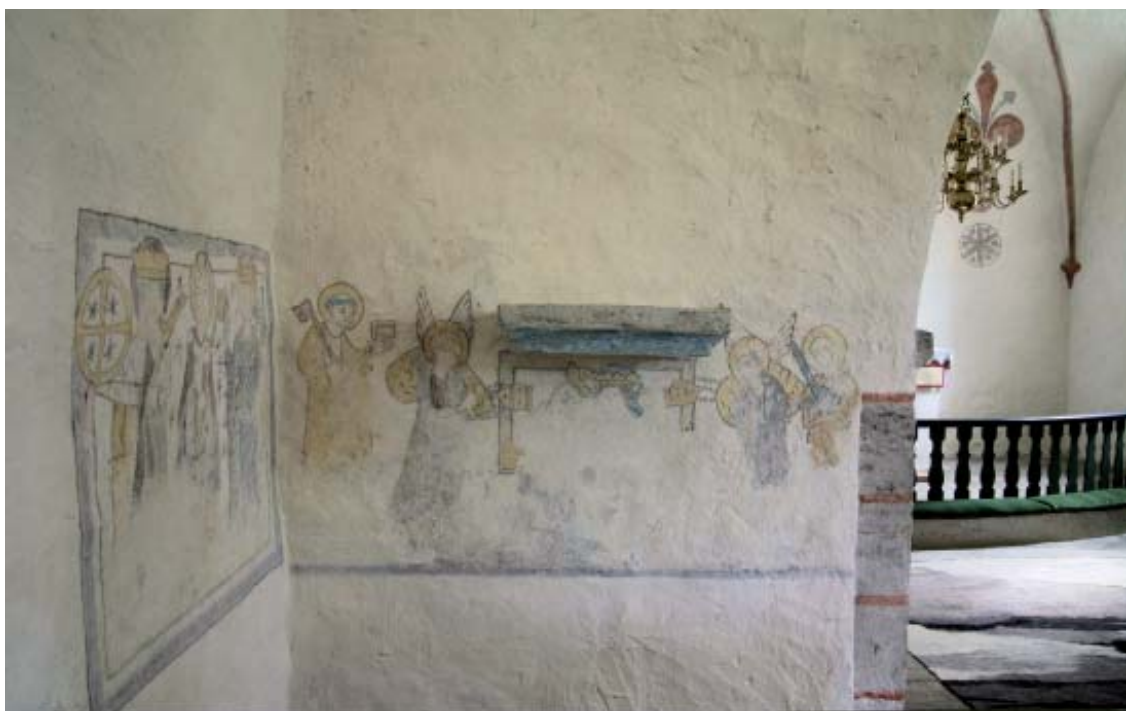

Fig. 9a. Hall (Sweden), village church: (a) wall paintings and console in the northeast corner of the nave, first half of the i4th century [photo Justin Kroesen] and (b) hypothetical reconstruction of the altar ensemble [drawing Justin Kroesen]

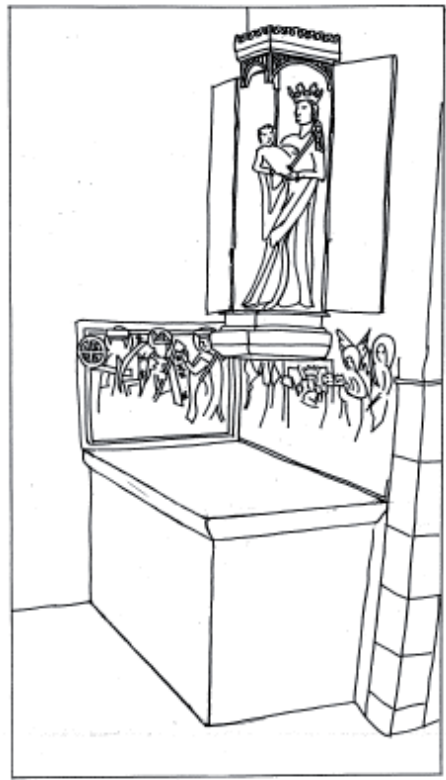

Fig. 9b. 


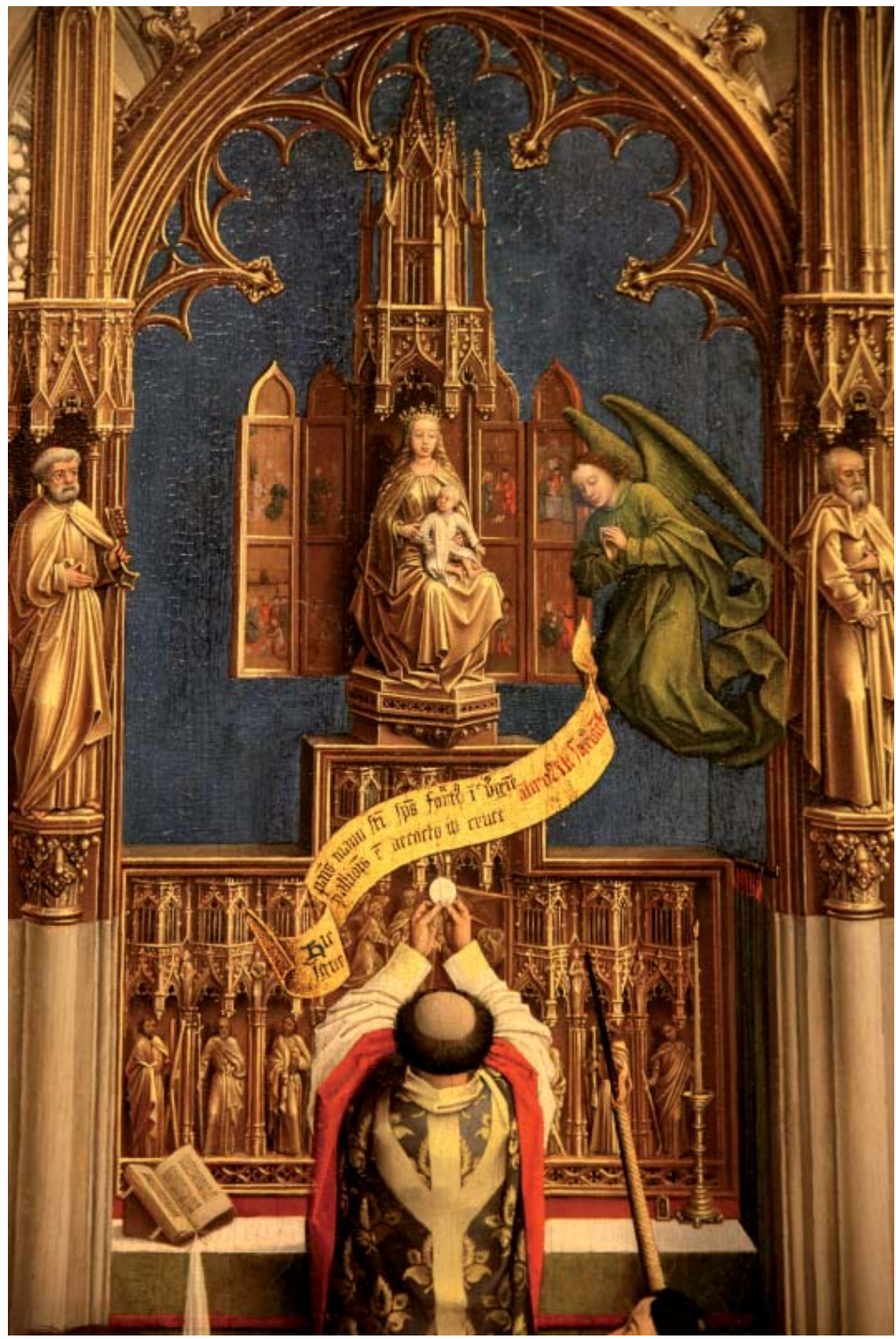

Fig. Io. Antwerp (Belgium), Museum voor Schone Kunsten, Seven Sacraments altarpiece by Rogier van der Weyden, ca. I440, detail with altar ensemble [photo Justin Kroesen]. 